\title{
ANTI-GIARDIASIS EFFECT OF ZINGIBER OFFICINALE ON GIARDIA LAMBLIA INFECTION AND THE IMMUNOLOGICAL RESPONSE IN EXPERIMENTALLY INFECTED IMMUNOCOMPETENT MICE \\ By \\ ZAKIAH NASSER ALMOHAWES \\ Department of Biology, Faculty of Science, Princess Nourah bint Abdulrahman \\ University, Riyadh, Kingdom of Saudi Arabia (znalmohawes@pnu.edu.sa)
}

\section{Abstract}

Giardia lamblia is a common protozoan parasite infects humans and is the most common cause of waterborne outbreaks of diarrhoeal diseases. The present study examined the anti-giardiasis effectiveness of ginger as a natural product in the prevention and treatment of G. lamblia in infected mice. Male albino mice were divided into the following four groups: 1 . Control uninfected untreated, 2. Infected with Giardia cysts and untreated, 3. Prophylactic with ginger before infection, and 4. Treated with ginger after infection. The results showed that Ginger resulted in a complete eradication of Giardia cysts in the faeces after infection by day 12 in the protected group and day 10 in the treated group. IFN- $\gamma$ levels were significantly decreased $(\mathrm{p}<0.05)$ in the ginger-protected and ginger-treated groups, and IL-5 levels were elevated in both ginger groups. Histopathological observations of the ileum support the immunological findings

Key words: Saudi Arabia, Anti-giardiasis lamblia, Ginger, Zingiber officinale, IFN- $\gamma$, IL-5.

\section{Introduction}

Giardia lamblia infections are considered to be a major public health problem, globally; however, the interactions of this parasite with the host are not fully understood, and effective vaccination strategies against this parasite do not exist for humans. G. lamblia is a flagellated unicellular eukaryotic enteric protozoan parasite that is responsible for one of the most common infections of the human intestine; this parasite is a leading cause of diarrhoeal disease worldwide (Jakubowski and Craun, 2002; Tian et al, 2010). This parasite is endemic in both high- and lowincome countries (Adam, 2001). In developed countries, Giardia is the most common cause of waterborne outbreaks of diarrhoeal disease (Slifko et al, 2000). Globally, approximately 1.5 million deaths occur each year from diarrhoeal diseases, and these deaths occur primarily in low-income settings and in children under 5 years old (WHO, 2015). A total of $2.0 \times 10^{8}$ people are estimated to have giardiasis, worldwide, each year, and children under the age of five are specifically at risk (Lane and Lloyd, 2002; Thompson, 2000). Associated with substantial economic losses, Giardia infection is a common cause of diarrhoeal disease in domestic animals (e.g., dairy calves, dogs, and cats) (Thompson, 2000). A fraction (20 to $80 \%$ ) of all stool-positive Giardia infections in humans are symptomatic infections (Flanagan, 1992; Nash et al, 1987), characterized by diarrhoea, epigastric pain, nausea, vomiting, and weight loss (Stifko et al., 2000). Symptoms typically appear 6 to 15 days after infection and last for 2 to 4 days. In more than $85 \%$ of cases, Giardiasis is self-limiting, which indicates that efficient host defences exist (Flanagan, 1992). CDC (2013) stated that nearly $2 \%$ of adults and 6 to $8 \%$ of children are currently infected with Giardia in developed countries, whereas a third of the people in the developing world have previously had giardiasis. Giardia cysts can survive for months in the soil and on the water surface. A detectable outbreak can occur even with very small concentrations of virulent and infectious cysts (Plutzer et al, 2010). These factors can be influenced by the higher Giardia prevalence in humans, estimated to be $10 \%$, compared to the 3 to $5 \%$ of Cryptosporidium (Huang and White, 2006). A better understanding of the immune response to the Giardia parasite may aid in the development of an appropriate therapeutic agent since there is currently no effective therapeutic agent with anti-giardial activity. The initial innate responses limit 
the parasite numbers; however, the clearance of the infection ultimately necessitates a cell-mediated immune response (Ungar et al, 1991; McDonald et al, 2004). Cytokines are proteins that play an important role in the modulation of innate and adaptive immune responses. In mice, studies have established that IFN- $\gamma$ is a primary player in cellmediated immunity as well as in the early innate immune responses (Theodos, 1998; Riggs, 2002; Lean et al, 2002). The majority of studies have reported that IFN- $\gamma$ activity is the most effective adaptive immune response to Giardia infection (Urban et al, 1996; Kapel et al, 1996). IL-5 is a cytokine that contributes to the humoural response and is produced by Th2 lymphocytes and takes part in the differentiation and growth induction of B- \& T-cells. IL-5 also stimulates the proliferation and differentiation of eosinophil precursors as well as their degranulation and production of reactive oxygen compounds. IL-5 induces eosinophilia by exerting a chemotactic effect on eosinophils (Faccioli et al, 1997; Weltman, 2000).

Nowadays, bioactive plants are antiparasitic treatment due to significant increase in resistance to chemical drugs (Kelley et al, 2016). Zingiber officinale Roscoe (ginger, Zingiberaceae), which is known for its flavour and pungency, is one of the most widely used spices in various foods and beverages. The rhizome of this plant is the primary part that is used for Chinese cuisine, medicinal herbs and condiments. It has been reported that $Z$. officinale exerts numerous pharmacological effects, such as antiulcer (Yoshikawa et al, 1994), antioxidant (Sadhana and Gupta, 2013), antibacterial (Mahady et al, 2003), antifungal (Ficker et al, 2003), anti-inflammatory (Jeena et al, 2013), antidiarrheal (Abouel-Nour et al, 2016), anthelminthic (Iqbal et al, 2001; El-Sayed et $a l, 2015$ ), and anticancer effects (Shukla and Singh, 2006). Extracts of Z. officinale were studied extensively for a wide range of biological activities, including anticonvulsant, analgesic, gastric anti-secretory, antispasmodic, and antiallergenic activities, as well as increasing digestive fluids and absorbing and neutralizing toxins and stomach acid. $Z$. officinale increased bile secretion and to increase the action and tone of the bowels (Bradley, 1992). Al-Masoudi (2011) reported the antigiardial activity of Zingiber officinale. The watery extract of this plant was shown to reduce the number of $G$. lamblia trophozoites.

This study aimed to investigate the antigiardiasis effectiveness of ginger as a natural medicinal plant to prevent and treat Giardia infections in immunocompetent mice that were experimentally infected. Though the role of cytokines in parasitic infections has been extensively studied in animal models, there is insufficient literature and clinical trials on the significance of the Th1 cytokine, IFN-gamma (IFN- $\gamma$ ), and the Th2 cytokine, interleukin- 5 (IL-5), in human giardiasis. Therefore, this work was performed to investigate the levels of these cytokines in the sera of mice infected with G. lamblia. Hence, this study aimed to assess the protective and therapeutic capacity of ginger against giardial infection.

\section{Materials and Methods:}

Plant material: Rhizomes of $Z$. officinale were obtained from a local market, and the roots were cut, washed with distilled water and dried in an oven at $50{ }^{\circ} \mathrm{C}$ for 5 to 7 days until they were completely dried. A grinder was used to grind the dried roots into a powder, which was stored at $4{ }^{\circ} \mathrm{C}$. The dose of ginger used for treatment was $50 \mathrm{mg} / \mathrm{kg}$ body weight/day, which was administered orally using a gastric tube 1 hour before breakfast.

Animals: A total of 20 male Swiss albino mice, three to five weeks old and weighing 25 to 30 grams, were used. The mice were housed in well-ventilated cages and provided with standard pellet food and water. All experimental procedures were approved by the Princess Nourah bint Abdualrahman University research ethics committee, IRB 
No. 18-0177. The mice were permitted to adjust to the laboratory environment for one week before the experiment (El-Fakhry et $a l, 1998)$, and they were free from any infection.

Mice infection: Giardia lamblia cysts were purchased from waterborne ${ }^{\mathrm{TM}}$, Inc. (New Orleans, Louisiana, USA) and stored in a shipping medium (phosphate-buffered saline with penicillin, streptomycin, gentamycin, amphotericin B \& $0.01 \%$ Tween 20) at $4{ }^{\circ} \mathrm{C}$ until use. Each mouse of the infected, experimentally protected, and experimentally treated groups was orally inoculated with the isolated Giardia cysts in a dose of $125 \times 10^{3}$ cysts/mouse (Gaafar, 2007). A 23-gauge needle tipped with plastic tubing was used for ingestion by gastric gavage (Riad et al, 2009).

Experimental design: Male Swiss Albino mice were divided into four equal groups of 5 mice each as follows: 1- Negative control group (uninfected, untreated) did not receive any treatment. 2- Infected group (positive control, infected, untreated); mice were inoculated orally with G. lamblia cysts in a dose of $125 \times 10^{3}$ cysts/mouse (Gaafar, 2007). 3 - Protected group; the mice received ginger (50mg/b.w./day) two days before infection, and continued to receive ginger daily for 12 days post-infection. 4- Experimental treated group; mice received ginger $(50 \mathrm{mg} /$ b.w./ day) one day after infection, and continued to receive ginger daily for 2 weeks.

Stool analysis: Samples were collected from all mice in separate plastic containers. Stools were inspected by direct wet saline smear, iodine and Sheather's sugar flotation method (Garcia and Brucker 1997). The experiment was conducted as follows: using an applicator stick, a small amount of faeces (approximately 2mg) was placed in the centre of the slide with a drop of saline. The sample was lightly stirred until thoroughly mixed with saline, and then a $22 \times 22 \mathrm{~mm}$ coverslip was placed on top of the mixture.
The mixture was examined using brightfield microscopy with low and high power objectives.

Immunological analysis: On day 17 postinfection, mice were anaesthetized (24 hrs after last dose in all groups). Each animal was kept fast for $12 \mathrm{hrs}$ before anaesthetization ether. Blood samples were withdrawn directly from heart. Blood was centrifuged at 3,000rpm to separate sera, which was stored at $-20^{\circ} \mathrm{C}$ until the concentration of IFN- $\gamma$ was determined using the QuantikineMIF00 mouse IFN- $\gamma$ ELISA immunoassay kit (R\&D, Minneapolis, MN, USA). IL-5 concentration was analysed using mouse IL5 ELISA Kit from RayBio ${ }^{\circledR}$ Company, according to the manufacturer's instructions.

Histological examination: After anaesthetized, the mice were sacrificed 17 days postinfection for the control, infected, and treated (using ginger) groups, while the mice of the ginger-protected group were sacrificed 15 days post-infection. Autopsy samples were obtained from the mice intestines of all groups and fixed in $10 \%$ neutral formalin for $24 \mathrm{hrs}$, washed with tap water, and then serial dilutions of ethanol (absolute) to dehydrate the samples. Specimens were cleared in xylene and embedded in paraffin at $56{ }^{\circ} \mathrm{C}$ in a hot air oven for $24 \mathrm{hrs}$. Paraffin beeswax tissue blocks were sectioned at a thickness of $4 \mu \mathrm{m}$ by sledge microtome. The tissue sections were collected on glass slides, deparaffinized, and stained with haematoxylin \& eosin for routine examination by a research light microscope (Banchroft et al, 1996).

Statistical analysis: Analysis was conducted among groups. Results were expressed as mean \pm S.E, and significance was analysed using the t- test.

\section{Results}

Stool showed cysts in infected group; in protected and treated groups. Cysts were absent in 12 days post-infection in protected group and 10 days in the treated group. 
Table 1: Stool analysis for all groups.

\begin{tabular}{|l|c|c|c|c|}
\hline Data collection & Negative Control & Positive Control & Protected & Treatment \\
\hline 1 week before infection & $-\mathrm{ve}$ & $-\mathrm{ve}$ & $-\mathrm{ve}$ & $-\mathrm{ve}$ \\
\hline 2 days before infection & $-\mathrm{ve}$ & $-\mathrm{ve}$ & $-\mathrm{ve}$ & $-\mathrm{ve}$ \\
\hline 2 days post infection $(\mathrm{PI})$ & $-\mathrm{ve}$ & $+\mathrm{ve}$ & $-\mathrm{ve}$ & $-\mathrm{ve}$ \\
\hline 4 days PI & $-\mathrm{ve}$ & $+\mathrm{ve}$ & $-\mathrm{ve}$ & $-\mathrm{ve}$ \\
\hline 6 days PI & $-\mathrm{ve}$ & $+\mathrm{ve}$ & $+\mathrm{ve}$ & $+\mathrm{ve}$ \\
\hline 8 days PI & $-\mathrm{ve}$ & $+\mathrm{ve}$ & $+\mathrm{ve}$ \\
\hline 10 days PI & $-\mathrm{ve}$ & $+\mathrm{ve}$ & $+\mathrm{ve}$ & $-\mathrm{ve}$ \\
\hline 12 days PI & $-\mathrm{ve}$ & $+\mathrm{ve}$ & $-\mathrm{ve}$ & $-\mathrm{ve}$ \\
\hline 14 days PI & $-\mathrm{ve}$ & $+\mathrm{ve}$ & $-\mathrm{ve}$ & $-\mathrm{ve}$ \\
\hline 16 days PI & $-\mathrm{ve}$ & $+\mathrm{ve}$ & $-\mathrm{ve}$ & $-\mathrm{ve}$ \\
\hline
\end{tabular}

Effect of G. lamblia infection and ginger protection and treatment on IFN- $\gamma$ levels in serum: Infection with Giardia cysts caused a significant increase $(\mathrm{P}<0.05)$ in the levels of IFN- $\gamma$ in the serum of the mice in the infected, untreated group compared with the uninfected and untreated group of mice. In the ginger-protected and -treated groups, there was a significant decrease $(\mathrm{P}<0.05)$ in IFN- $\gamma$ levels in serum compared to infected group. Moreover, there was a significant increase in IFN- $\gamma$ levels in serum of the ginger-protected and -treated groups compared to uninfected control group.

Table 2: Concentration of IFN- $\gamma$ \& IL-5 in serum of mice in each group.

\begin{tabular}{|c|c|c|c|c|}
\hline Treatment & Negative Control & Positive Control & Protected & Treatment \\
\hline IFN- $\gamma(\mathrm{pg} / \mathrm{mL})$ & $126.7 \pm 0.6^{\mathrm{b}}$ & $800.8 \pm 1.5^{\mathrm{a}}$ & $207.8 \pm 0.8^{\mathrm{ab}}$ & $168.8 \pm 0.7^{\mathrm{ab}}$ \\
\hline IL-5 $(\mathrm{pg} / \mathrm{mL})$ & $182 \pm 6^{\mathrm{b}}$ & $95.3 \pm 0.9^{\mathrm{a}}$ & $143 \pm 4^{\mathrm{ab}}$ & $103 \pm 0.8^{\mathrm{a}}$ \\
\hline
\end{tabular}

${ }^{a}$ significant compared to control $(\mathrm{P}<0.05){ }^{\mathrm{b}}$ significant compared to infected group $(\mathrm{P}<0.05)$.

Effect of giardiasis, ginger protection and treatment on serum IL-5 Levels: Infection with Giardia cysts resulted in a significant decrease $(\mathrm{P}<0.05)$ in IL-5 levels in the serum of the infected untreated group of mice compared with the uninfected control group. In contrast, there was a significant increase in IL-5 levels in the ginger-protected group compared to the infected group. In addition, there was a significant decrease $(\mathrm{P}<0.05)$ in the ginger-protected and ginger-treated groups compared with the uninfected group. Histopathological study: 1- Control group with their ileum sections of the control mice exhibited normal architecture of the villi. 2Infected group but untreated, their ileum sections exhibited histopathological alterations. 3- Experimental prophylactic group their ileum sections prepared from mice treated with ginger exhibited histopathological alterations compared to controls. 4- Experimental therapeutic group their ileum sections prepared from mice treated with ginger exhibited histopathological alterations compared to controls

\section{Discussion}

In the present study, mice that were used were free from any type of infection. Additionally, the infectivity of the mice was successful, and the protected and treated groups were all infection-free by day 12 and 10 post-infection (PI), respectively. This finding indicates that ginger effectively removed Giardia Lamblia from the body and, when compared to the control infected group, which was still showing positive results of infection by passing cysts in the stool until the end of the experiment at day 16 PI, there were no signs of infection in the stools of the ginger-protected and ginger-treated groups.

Giardia is primarily an intestinal parasite, which induces changes in the immune system to overcome the infection; these changes may be reflected in the production of immune mediators. The variations in cytokines 
and immunoglobulin levels may allow for the establishment of a distinctive profile related to infection by Giardia, although these cytokines are produced in small quantities.

In this study, an increase in IFN- $\gamma$ cytokine secretion was detected in the infected mice compared to the non-infected control mice, which indicates that the infected mice exhibited an immune response, which attempted to overcome the infection. The increased expression of the immune mediator IFN- $\gamma$ was observed during the infection, indicating that the immune response seems to be mostly a Th1-mediated response. This finding is in line with (McDonald, 2000). Multiple studies have demonstrated the critical role of IFN- $\gamma$ in the host resistance to infection with another parasite, Trypanosoma cruzi (Aliberti et al, 1996; Cardillo et al, 1996). After infection, a primary response against Giardia was detected by the significant increase in the level of IFN- $\gamma$. The balance between Th1 (to control parasite growth) and Th2 cytokines (to limit pathology) is delicate, and this finding is in line with (Lean et al, 2002; Tessema et al, 2009).

The administration of Giardia cysts caused a significant decrease $(\mathrm{P}<0.05)$ in the IL-5 levels in the serum of the infected untreated group of mice compared with the control group. On the other hand, there was a significant increase in IL-5 levels in the ginger-protected group compared to the infected group. Comparing ginger-protected group with the uninfected group, there was a significant decrease in IL-5 levels. Nevertheless, in the ginger-treated groups, there was a significant decrease in IL-5 level in comparison to the uninfected group. Several studies have indicated the variations in the levels of immunological indices during parasitic invasions, e.g., the observed increase in IL-5 that is typical of parasitosis (Faccioli et al, 1997). Matowicka-Karna et al. (2009) performed research on patients infected with G. lamblia and confirmed a statistically significant increase in IL-5 levels. In the acute form of Schistosoma mansoni infection course, the levels of IL -5 \& IFN- $\gamma$ exhibited a marked increase (de Jesus et al, 2002). In response to the administration of the extract of a soluble antigen of Onchocerca volvulus, an increase in IL-5 \& IL-13 was observed (Brattig et al, 2002). Cooper et al. (2001) described the early stage of Onchocerca volvulus infection, which caused an increase in the production of IL-5 \& IFN- $\gamma$. Ajdary et al. (2009) detected a significant increase in the levels of IL-5, IFN- $\gamma$ \& IL-13 in patients who were chronically infected with Leishmania (but untreated), produced by peripheral blood mononuclear cells (PBMC) in vitro. These findings suggest the occurrence of a mixed Th1/Th2 response; nonetheless, patients with acute disease displayed a Th1 response, which was confirmed by the increase in the levels of IFN- $\gamma$ and the low levels of IL-5 \& IL-13. Ishikawa et al. (1998) reported that experimental mice infected with Trichinella spiralis and Nippostrongylus brasiliensis exhibited the release of IL-5 and IFN- $\gamma$ from Th1 and Th2 cells. This finding is in accordance with the present study. The synthesis and release of IgE are suppressed by IFN- $\gamma$, which is produced by activated Th1 cells. IFN- $\gamma$ stimulates the elimination of intracellular parasites by macrophages by inducing the production of reactive oxygen and the secretion of hydrogen peroxide (Lucey et al, 1996). Touil-Boukoffa et al. (1997) demonstrated that the defence mechanisms that are activated in the course of echinococcosis also involve IL-6 and IFN- $\gamma$. Ajami and Rafiei (2007) on Hymenolepis nana-infected patients found an increase in the levels of IL-5, IL-12, IL-13 and IFN- $\gamma$.

In this study, there was a decrease in IL-5 levels, whereas IFN- $\gamma$ levels were elevated in Giardia-infected mice. Th1 lymphocytes produce IFN- $\gamma$, which contributes to the cellular type response and inhibits the proliferation and action of Th2 cells. Th2 lymphocytes produce IL-4, IL -5, IL-6, IL-10 \& IL13 and stimulate the humoural response. In the present study, the antiparasitic treatment 
in mice infected with Giardia caused a statistically significant increase in the levels of IL-5 and a significant decrease in the IFN- $\gamma$ levels of the treated groups, as shown above. This indicated that immune and inflammatory responses in parasitic invasions course wherein IFN- $\gamma$, TNF, IL-1b, IL-5 \& IL-13 are generated (Ajdary et al, 2009).

These results could serve as guidelines for future studies on the immune response to Giardia in immunocompetent populations. Significant advances have been made towards understanding the host responses against Giardia, along with immune effector mechanisms that control infection, although there are still important gaps in the understanding of the immune mediators that are involved. In this context, this work provides preliminary information, supporting the role of IFN- $\gamma$ and IL-5 as the key cytokines in both innate and adaptive immunity during primary and secondary G. Lamblia infection. The kinetics of IFN- $\gamma$ expression reflect the pattern of acute infection, which has been observed in neonatal mice, with the levels of IFN- $\gamma$ increasing as infection progresses to a peak level and falling rapidly as recovery begins (Kapel et al, 1996; McDonald $e t$ al, 2004). Principal functions of IFN- $\gamma$ and other proinflammatory cytokines include triggering antimicrobial killing mechanisms, such as the generation of toxic nitric oxide derivatives or oxygen radicals, or causing a deficiency of metabolites which are essential for the growth of microorganisms, such as tryptophan or cellular iron (Rottenberg et al, 2002). IFN- $\gamma$ stimulates the production of high levels of nitric oxide and frequently acts in concert with other cytokines, such as TNF- $\alpha$ (Nacy et al, 1991).

The results of the histopathological examination of the intestinal mucosa of the infected non-treated group are in agreement with multiple studies (Buret, 2005; Abdel-Fattah and Nada, 2007; Abdalla et al, 2011; Fathy, 2011; Mahmoud et al, 2014; Ismail et al, 2017). Numerous host factors, in addition to the interaction between trophozoites and the intestinal epithelium, were responsible for the microvillus changes and epithelial barrier dysfunction observed in the case of giardiasis (Scott et al, 2000; Chin et al, 2002). The histopathological examination of the intestinal mucosa of both ginger groups revealed some recovery of the pathological changes of the ileum mucosa and villous architecture. These results were similar to those of other studies (Mahmoud et al, 2014; Dyab et al, 2016), and this finding suggests the protective and therapeutic capacity of ginger against giardial infection.

\section{Conclusion}

It is clear that the immune response was elevated to clear the infection as a result of the treatment strategies employed in this study, which appeared to increase the release of cytokines when compared with the uninfected and infected controls. Z. officinale exerts an effective anti-parasitic activity against $G$. lamblia and can be used for the prevention of drug-resistant diseases; however, more evaluation is necessary to isolate the active components and determine their toxicity, side effects and pharmacokinetic properties.

\section{Acknowledgement}

The author would like to thanks the Authorities of Princess Nourah Bint Abdulrahman University, Kingdom of Saudi Arabia for kindly providing facilities and funding.

Conflict of interest: The author has no conflict of interest.

\section{References}

Abdalla, S.F, Ramadan, NI, Mohamed, MAA, El-Deeb, HK, Al-Khadrawy, FM, Badawy, A F, 2011: A study on the effect of Myrtus communis and Olibanum on Giardia lamblia infection in Egypt. PU J, 4, 1: 89-100.

Abdel-Fattah, NS, Nada, OH, 2007: Effect of propolis versus metronidazole and their combined use in treatment of acute experimental giardiasis. J. Egypt. Soc. Parasitol. 37, 2: S691710.

Abouel-Nour, MF, El-Shewehy, DMM, Hamada, SF, Morsy, TA, 2016: The efficacy of three medi-cinal plants; garlic, ginger and mirazid and 
a chemical drug metronidazole against Cryptosporidium parvum: ii- Histological changes. J. Egypt. Soc. Parasitol. 46, 1:185-200.

Adam, RD, 2001: Biology of Giardia lamblia. Clin. Microbiol. Rev. 14:447-75.

Ajami, A, Rafiei, A, 2007: Cytokine production in Hymenolepis nana infection. Iranian J. Immunol. 4:236-40.

Ajdary, S, Riazi-Rad, F, Alimohammadian, MH, Pakzad, SR, 2009: Immune response to Leishmania antigen in anthroponotic cutaneous leishmaniasis. J. Infect. 59, 2:139-43.

Aliberti, JC, Cardoso, MA, Martins, GA, Gazzinelli, RT, Vieira, LQ, et al, 1996: Interleukin-12 mediates resistance to Trypanosoma cru$z i$ in mice and is produced by murine macrophages in response to live trypomastigotes. Infect. Immun. 64, 6:1961-7.

Al-Masoudi, HK, 2011: Antigiardial activity of Zingiber officinale in combination with honey in vivo. J. Babylon Uni./Pure Appl. Sci. 2, 19:4504.

Bradley, PR, 1992: British herbal compendium: British herbal medicine association, Bournemouth, Dorset, UK. 1:112-114.

Buret, AG, 2005: Immunopathology of giardiasis: The role of lymphocytes in intestinal epithelial injury and malfunction. Mem. Inst. Oswaldo Cruz 100, 1:185-90.

Cardillo, F, Voltarelli, JC, Reed, SG, Silva, J S, 1996: Regulation of Trypanosoma cruzi infection in mice by gamma interferon and interleukin 10: role of NK cells. Infect. Immun. 64:12834.

CDC, 2013: Surveillance for waterborne disease outbreaks associated with drinking water and other non-recreational water United States, 2009 -2010. MMWR 62:35-9.

Chin, AC, Teoh, DA, Scott, KGE, Meddings, JB, Macnaughton, WK, et al, 2002: Strain-dependent induction of enterocyte apoptosis by Giardia lamblia disrupts epithelial barrier function in a caspase-3-dependent manner. Infect. immun. 70, 7:3673-80.

Cooper, PJ, Mancero, T, Espinel, M, et al, 2001: Early human infection with Onchocerca volvulus is associated with an enhanced parasitespecific cellular immune response. J. Infect. Dis. 183:1662-8.

de Jesus, AR, Silva, A, Santana, LB, et al, 2002: Clinical and immunological evaluation of 31 patients with acute schistosomiasis mansoni. J. Infect. Dis. 185:98-105.
Dyab, AK, Yones, DA, Ibraheim, ZZ, Hassan, TM, 2016: Anti-giardial therapeutic potential of di-chloromethane extracts of Zingiber officinale and Curcuma longa in vitro and in vivo. Parasitol. Res. 115, 7:2637-45.

El-Fakhry, Y, Achbarou, A, Desportes, I, Mazier, D, 1998: Encephalitozoon intestinalis: Humoral responses in interferon-gamma receptor knockout mice infected with a Microsporidium pathogenic in AIDS patients. Exp. Parasitol. 89: 113-21.

El-Sayed, NM. Magda Mostafa El-Saka, MM, 2015: Anti-parasitic activity of Zingiber officinale (Ginger): A brief review. Aperito J. Bacteriol. Virol. Parasitol. 2, 1:112-9

Faccioli, LH, Vargaftig, BB, Medeiros, A, Malheiros, A, 1997: Cytokines in the modulation of eosinophilia. Mem. Inst. Oswaldo Cruz Rio de Janeiro 92, 11:S109-14.

Fathy, FM, 2011: Effect of mirazid (Commiphora molmol) on experimental giardiasis. J. Egypt. Soc. Parasitol. 41, 1:155-77.

Ficker, CE, Smith, ML, Leaman, DL, Irawati, C, Arnason, JT, 2003: Inhibition of human pathogenic fungi by member of Zingiberaceae: Used by kenyah (Indonesian Borneo). J. Ethnopharmacol. 85:289-93.

Flanagan, PA, 1992: Giardia- diagnosis, clinical course and epidemiology: A review. Epidemiol. Infect. 109:1-22.

Gaafar, MR, 2007: Effect of solar disinfection on viability of intestinal Protozoa in drinking water. J. Egypt. Soc. Parasitol. 37:65-86.

Garcia, LS, Bruckner, DA, 1997: Macroscopic and microscopic examination of fecal specimens. In: Diagnostic Medical Parasitology $3^{\text {rd }}$ ed. Washington D.C. AMS Press.

Huang, DB, White, AC, 2006: An updated review on Cryptosporidium and Giardia. Gastroenterol. Clin. North Am. 35:291-314.

Iqbal, Z, Nadeem, QK, Kkan, MN, Akhtar, M S, Waraich, FN, 2001: In vitro anti-hel-minthic activity of Allium sativum, Zingiber officinale, Curcurbita mexicana and Ficus religiosa. Inter. J. Agricul. Biol. 3:454-7.

Ishikawa, N, Goyal, PK, Mahida, YR, Li, KF, Wakelin, D, 1998: Early cytokine responses during intestinal parasitic infections. Immunology 93:257-63.

Ismail, HI, Ashour, DS, Saad, AE, Rizk, OK, 2017: Impact of immune suppression on histopathological and immunological parameters of 
mice experimentally infected with Giardia lamblia. J. Egypt. Soc. Parasitol. 47, 1:197-206.

Jakubowski, W, Craun, GF, 2002: Update on the control of Giardia in water supplies. In: Olson BE, Olson ME, Wallis PM, eds. Giardia, the Cosmopolitan Parasite. Oxon, Wallingford: CABI, U.K.

Jeena, K, Liju, VB, Kuttan, R, 2013: Antioxidant, anti-inflammatory and antinociceptive activities of essential oil from ginger. Indian $J$. Physiol. Pharmacol. 57:51-62.

Kapel, N, Benhamou, Y, Buraud, M, Magne, D, Opolon, O, et al, 1996: Kinetics of mucosal ileal gamma-interferon response during cryptosporidiosis in immunocompetent neonatal mice. Parasitol. Res. 82:664-7.

Kelley, JM, Elliott, TP, Beddoe, T, Anderson, G, Skuce, P, et al, 2016: Current threat of triclabendazole resistance in Fasciola hepatica. Trends Parasitol. 32, 6:458-69.

Lane, S, Lloyd, D, 2002: Current trends in research into the waterborne parasite Giardia. Crit. Rev. Microbiol. 28, 2:123-47.

Lean, IS, McDonald, V, Pollok, RC, 2002: The role of cytokines in the pathogenesis of Cryptosporidium infection. Curr. Opin. Infect. Dis. 15, 3:229-34.

Mahady, GB, Pendl, SL, Yun, GS, Lu, ZZ, Stoia, A, 2003: Ginger (Zingiber officinale) and the gingerols inhibit the growth of $\mathrm{Cag} \mathrm{A}+$ strains of Helicobacter pylori. Anticancer Res. 23:3699-702.

Mahmoud, A, Attia, R, Safaa, SAID, Ibraheim, Z, 2014: Ginger and cinnamon: can this household remedy treat giardiasis? Parasitological and histopathological studies. Iranian J. Parasitol. 9, 4:530-6.

Matowicka-Karna, J, Dymicka-Piekarska, V, Kemona, H, 2009: IFN-gamma, IL-5, IL-6 and $\mathrm{IgE}$ in patients infected with Giardia intestinalis. Folia Histochemica et Cytobiologica/ Polish Academy of Sciences/Polish Histochemical and Cytochemical Society 47:93-7.

McDonald, SA, O'Grady, JE, Bajaj-Elliott, M, Notley, CA, Alexander, J, et al, 2004: Protection against the early acute phase of Cryptosporidium parvum infection conferred by interleukin-4-induced expression of T helper 1 cytokines. J. Infect. Dis. 190:1019-25.

McDonald, V, 2000: Host cell-mediated res= ponses to infection with Cryptosporidium. Parasite Immunol. 22:597-604.
Nacy, CA, Meierovics, AI, Belosevic, M, Green, SJ, 1991: Tumor necrosis factor-alpha: Central regulatory cytokine in induction of macrophage antimicrobial activities. Pathobiol. 59: 182-4.

Nash, TE, Herrington, DA, Losonsky, GA, Levine, MM, 1987: Experimentalhuman infections with Giardia lamblia. J. Infect. Dis. 156: 974-84.

Plutzer, J, Ongerth, J, Karanis, P, 2010: $G i$ ardia taxonomy, phylogeny and epidemiology: facts and open questions. Int J. Hyg. Environ. Hlth. 213:321-33.

Riad, NHA, Taha, HA, Mahmoud, YI, 2009: Effects of garlic on albino mice experimentally infected with Schistosoma mansoni: A parasitological and ultrastructural study. Trop. Biomed. 26:40-50.

Riggs, MW, 2002: Recent advances in cryptosporidiosis the immune response. Microb. Infect. 4, 10:1067-80.

Rottenberg, ME, Gigliotti-Rothfuchs, A, Wigzell, H, 2002: The role of IFN- $\gamma$ in the outcome of chlamidial infection. Curr. Opin. Immunol. 14:444-51.

Sadhana, S, Gupta, AK, 2013: Evaluation of phenolics content, flavonoids and antioxidant activity of Curcuma amada (mango ginger) and Zingiber officinale (ginger). Res. Rev. J Chem. 13, 2:32-5.

Scott, KE, Logan, MR, Klammer, GM, Teoh, DA, Buret, AG, 2000: Jejunal brush border microvillous alterations in Giardia muris-infected mice: Role of $\mathrm{T}$ lymphocytes and interleukin6. Infect. Immun. 68, 6:3412-8.

Shukla, Y, Singh, M, 2006: Cancer preventive properties of ginger: a brief review. Food Chem. Toxicol. 45, 5:683-90.

Slifko, TR, Smith, HV, Rose, JB, 2000: Emerging parasite zoonoses associated with water and food. Int. J. Parasitol. 30: 1379-93.

Tessema, TS, Schwamb, B, Lochner, M, Forster, I, Jakobi, V, et al, 2009: Dynamics of gut mucosal and systemic Th1/Th2 cytokine responses in interferon-gamma and interleukin-12 p40 knockout mice during primary and challenge Cryptosporidium parvum infection. Immunobiol. 214: 454-66.

Theodos, CM, 1998: Innate and cell-mediated immune responses to Cryptosporidium parvum. Adv. Parasitol. 40:87-119. 
Tian, H, Chen, B, Wen, J, 2010: Giardiasis, drug resistance and target discovery. Infect. Disorders Drug Targets.10:259-302.

Thompson RC. 2000: Giardiasis as a re-emerging infectious disease and its zoonotic potential. Int. J. Parasitol. 30: 1259-67.

Touil-Boukoffa, C, Sanceau, J, Tayebi, B, Wietzerbin, J, 1997: Relationship among circulating interferon, tumor necrosis factor alpha, and interlekin- 6 and serologic reaction against parasitic antigen in human hydatidosis. J. Interferon Cytok. Res.17:211-7.

Ungar, BL, Kao, TC, Burris, JA, Finkelman, FD, 1991: Cryptosporidium infection in an adult mouse model: Independent roles for IFN-gamma and CD4+ T lymphocytes in protective immunity. J. Immunol. 147:1014-22.
Urban, JF, Jr, Fayer, R, Chen, SJ, Gause, W C, Gately, MK, et al, 1996: IL-12 protects immunocompetent and immunodeficient neonatal mice against infection with Cryptosporidium parvum. J. Immunol. 156:263-8.

Weltman, JK, 2000: Cytokines: regulators of eosinophilic inflammation. Allergy Asthma Proceed. 21:203-7.

WHO, 2015: Global Health Observatory Data 2012. Available: http://www.who.int/gho/en/.

Yoshikawa, MS, Yamagashi, K, Kumini, H, Matsuda, Y, Okuno, J, et al, 1994: Stomachic principle in ginger. Anti-ulcer principle, 6gingesulfonicacid and three mono acyl digalactosy glycerols ginger glycolipids A, B and C, from Zingiber rhizome originating in Taiwan. Chem. Pharma. Bull. 2:226-30.

\section{Explanation of figures}

Fig. 1: Cross-section of ileum of uninfected control mice showing normal structures of villi (V), a regular and continuous brush border (BB), absorptive columnar cells (AC) and lamina propria (LP) (H\&E, x100).

Fig. 2: Cross-section of ileum of control infected mice showing disturbed villous architecture, hyperplasia of the villi (V) with local ulceration (LU) $(\mathrm{H} \& \mathrm{E}, \times 100)$.

Fig. 3: Villi of uninfected control mice showing normal structure of villi (V), a regular and continuous brush border (BB), presence of goblet cells between enterocytes (GC), and normal connective tissue core of villi (LP) (H\&E, $\times 400)$.

Fig. 4: Villi of control infected mice showing degeneration of columnar epithelium (AC) with many pyknotic nuclei (PK) and a denucleated brush border $(\mathrm{BB})(\mathrm{H} \& \mathrm{E}, \times 400)$.

Fig. 5: Ileum of uninfected control mice showing normal structures of crypts of Lieberkühn (CL) (H\&E, $\times 200)$.

Fig. 6: Photomicrograph of a representative ileum of control infected mice showing mild oedema with very mild inflammatory infiltrate in the crypts of Lieberkühn $(\mathrm{CL})(\mathrm{H} \& \mathrm{E}, \times 200)$.

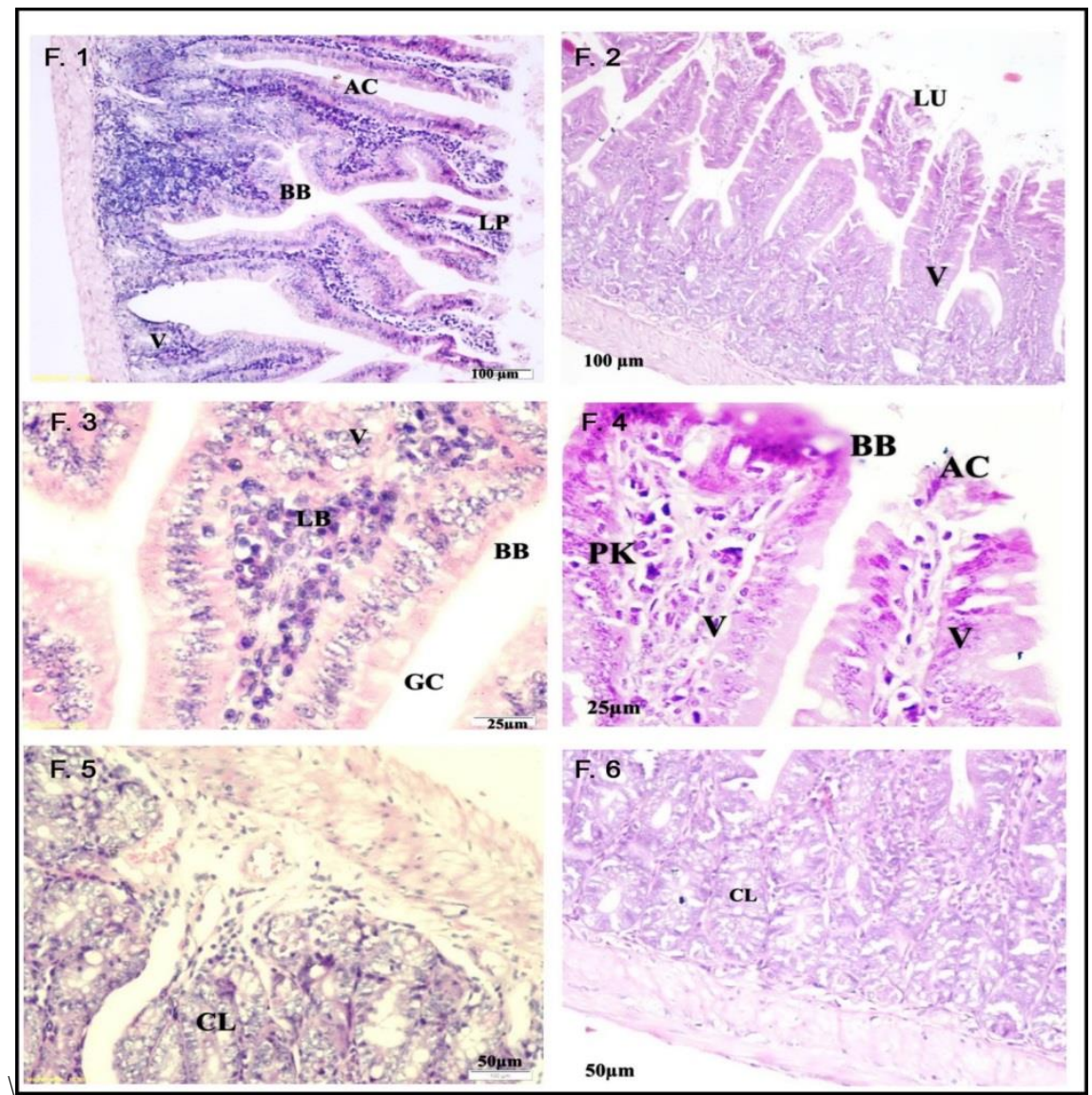




\section{Explanation of figures}

Fig. 7: Cross-section of ileum of ginger-protected mice showing nearly normal villi (V), apart from mild atrophy $(\mathrm{AT})(\mathrm{H} \& \mathrm{E}, \times 100)$. Fig. 8: Villi of ginger-protected mice showing very mild degeneration of columnar epithelium (AC) with a preserved brush border (BB) $(\mathrm{H} \& \mathrm{E}, \times 400)$.

Fig. 9: Ileum of ginger-protected mice showing normal crypts of Lieberkühn (CL) with no evidence of inflammation (H\&E, $\times 200)$. Fig. 10: Cross-section of ileum of ginger-treated mice showing nearly normal villi structure (V), a regular and continuous brush border (BB), normal absorptive columnar cells (AC) and lamina propria (LP) $(\mathrm{H} \& \mathrm{E}, \times 100)$

Fig. 11: Villi of ginger-treated mice showing nearly normal villi (V), normal absorptive columnar cells (AC), a regular and continuous brush border (BB), and normal connective tissue core (LP) (H\&E, $\times 400)$.

Fig. 12: Cross-section of ileum of ginger-treated mice showing normal crypts of Lieberkühn (CL) with no evidence of inflammation (H\&E, ×200).

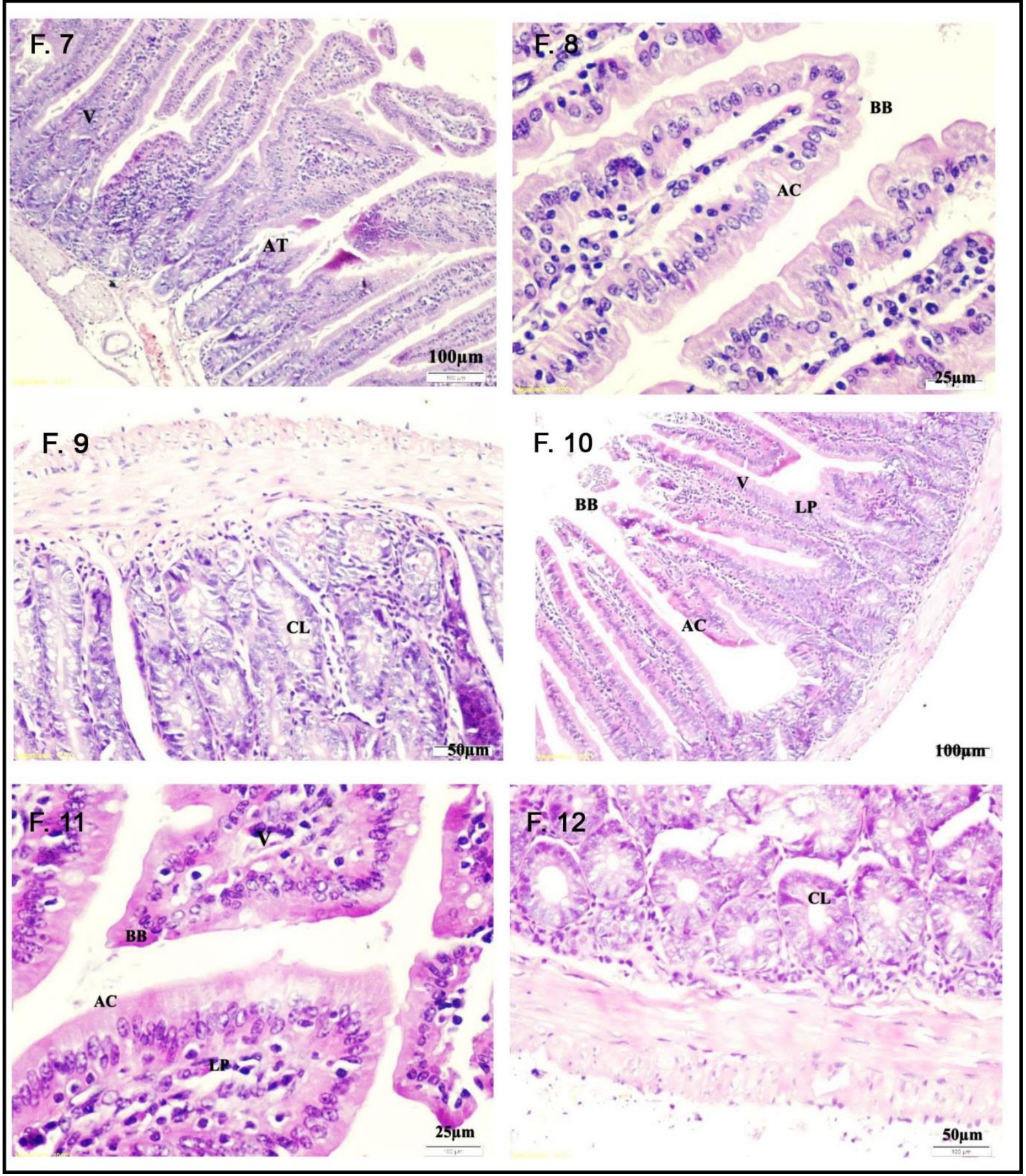

